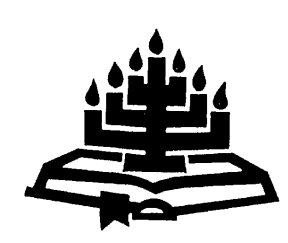

\title{
Die Gereformeerde Kerke in Suid-Afrika 1859-2002: die vervulling van 'n roeping in belang van die koninkryk van God?
}

\author{
A. le R. du Plooy \\ Fakulteit Teologie \\ Potchefstroomse Universiteit vir $\mathrm{CHO}$ \\ POTCHEFSTROOM \\ E-pos: dtlaldp@puknet.puk.ac.za
}

\begin{abstract}
The Gereformeerde Kerke in Suid-Afrika 1859-2002: Fulfilment of a calling for the benefit of the Kingdom of God?
\end{abstract}

The Gereformeerde Kerke in Suid-Afrika was founded on 11 February 1859 in Rustenburg. This article looks at a number of subthemes from the history of the GKSA. These sub-themes represent a random choice but are relevant to the topic. Though not meant to cover the entire field, the following sub-themes are discussed:

- $\quad$ The historical context within which the Gereformeerde Kerke in Suid-Afrika originated in 1859.

- $\quad$ The fundamental calling of the church to proclaim the Word of God in its purest form, and the importance of providing sound, scholarly education and training to theological students.

- $\quad$ The calling to actualise the unity of the church, with reference to the relationship among the three major Afrikaans-speaking reformed denominations, ecumenism and unity across ethnic and language boundaries.

- $\quad$ The calling to ensure justice in society, with brief reference to the Gereformeerde Kerke in Suid-Afrika and the ideology of apartheid.

- $\quad$ The calling to bear testimony among people in society. 
Opsomming

Die Gereformeerde Kerke in Suid-Afrika 1859-2002: die vervulling van 'n roeping in belang van die koninkryk van God?

Die Gereformeerde Kerke in Suid-Afrika is op 11 Februarie 1859 in Rustenburg gestig. In hierdie artikel word op 'n aantal subtemas uit die geskiedenis van die Gereformeerde Kerke in Suid-Afrika gefokus. Dit is temas wat willekeurig gekies is, en is nie bedoel om volledig te wees nie. Die volgende subtemas kom agtereenvolgens aan die orde:

- Die historiese konteks waarin die Gereformeerde Kerke in SuidAfrika in 1859 ontstaan het.

- Die prominente roeping van die kerk om die Woord van God suiwer te verkondig, en die belangrikheid van 'n wetenskaplike en suiwer opleiding van teologiese studente.

- Die roeping om die eenheid van die kerk gestalte te gee, in sowel nasionale as internasionale (of ekumeniese) verband.

- Die roeping om geregtigheid in die samelewing te verseker, met besondere verwysing na die Gereformeerde Kerke in Suid-Afrika en die ideologie van apartheid.

- Die roeping tot getuienis in die samelewing.

\section{Inleiding}

Die opskrif van hierdie artikel dui aan dat daar binne 'n bepaalde konteks na die Gereformeerde Kerke in Suid-Afrika gekyk word. Om te ontkom aan 'n kerksentriese benadering asof die kerk - en dan in besonder die Gereformeerde Kerke in Suid-Afrika - die doel of fokuspunt is, word 'n koninkryksbenadering gevolg, en word die vraag of die Gereformeerde Kerke in Suid-Afrika instrumenteel sy roeping in hierdie verband vervul, aan die orde gestel.

Die bedoeling is verder nie om 'n oorsig oor die geskiedenis van die Gereformeerde Kerke sedert die ontstaan van die Gereformeerde Kerk te Rustenburg op 11 Februarie 1859 te gee nie, maar om aan die hand van enkele deurlopende onderwerpe, aandag aan die afgelope 50 jaar te gee - hoewel steeds binne die gesigsveld van die geskiedenis wat dit voorafgaan.

Uiteraard moet 'n seleksie van sulke onderwerpe gemaak word, en kan binne die ruimte tot my beskikking nie aan ander temas aandag gegee word nie. Ek meen dat die volgende willekeurige seleksie aktuele en belangrike onderwerpe is in hierdie verband: 
- Die historiese konteks waarbinne die Gereformeerde Kerke in SuidAfrika in 1859 ontstaan het.

- Die belangrikheid van die roeping tot die suiwer bediening van die Woord, sakramente en die kerklike tug.

- As subtemas word hier gelet op

- die teologiese opleiding en die beoefening van die teologie, asook op

- enkele perspektiewe op die verhouding tussen die Gereformeerde Kerke in Suid-Afrika en die PU vir CHO.

- Die roeping tot eenheid, waaronder die volgende subtemas aan die orde kom:

- eenheid tussen die drie Afrikaanse kerkgemeenskappe;

- ekumenisiteit;

- sending en kerkeenheid oor volks- en taalgrense heen en die verhouding met ander Nasionale Sinodes (Middellande en Soutpansberg).

- Die roeping tot geregtigheid in die samelewing, waaronder gefokus word op die Gereformeerde Kerke in Suid-Afrika en die ideologie van apartheid.

- Die roeping tot getuienis in die samelewing.

\section{Historiese konteks waarbinne die Gereformeerde Kerke in Suid-Afrika ontstaan het}

Gedurende die tydperk van die begin tot die middel van die negentiende eeu het daar in die geledere van die gereformeerde kerkfamilie in die wêreld verskillende afskeidings plaasgevind, byvoorbeeld in Nederland (1834), in Skotland (1843), in die Verenigde State van Amerika (1857), en in Suid-Afrika (1859).

Die gemeenskaplike faktore wat hiertoe aanleiding gegee het, was die invloed of effek van geestestrominge waaronder die Franse Rewolusie, die Verligting, rasionalisme, piëtisme, metodisme en kollegialisme.

Hanekom (1951:9) sien die 18de eeu as 'n ongunstige oorgangsperiode vir die ontwikkeling van die kerklike lewe, omdat onder die druk van die liberalisme, die kenmerkende eienskappe van die gereformeerde kerk verlore gegaan het.

Aan die begin van die negentiende eeu, na die oorname van die Kaap deur die Engelse, is die sogenaamde "moderne" rigting hier gevestig. Dit 
is ' $n$ rasionalistiese liberalisme wat die reg vir die individu opeis om die Skrif te kritiseer, wonders te verwerp en bepaalde leerstukke te betwis (vgl. Spoelstra, 1963:6-7; Hanekom, 1951:x-xiii).

Hierdie koue verstandsgodsdiens het ruimte geskep vir 'n reaksie waar die ervaring en emosie van die mens 'n plek in die godsdiens moes verkry. In die metodisme van die laat 18de en 19de eeue is 'n ondogmatiese Christendom bepleit waar die belydende aard van die kerk van minder belang geag is, en waar op remonstrantse of pelagiaanse wyse veronderstel is dat die mens die vermoë het om homself te bekeer (vgl. Du Toit, 1903: ix, 120-179). Die sola Scriptura van die Reformasie is vervang deur die rasionele vermoëns van die mondige mens. Verder het die gedagte ontstaan dat die Heilige Gees buite die Woord om mense se verstand kan verlig om tot besondere insigte te kom.

Waar die Reformasie opnuut ontdek het dat die mens alleen op grond van God se genade gered kan word, en dat al die klem op ons geloof in God geplaas moet word (sola gratia en sola fide), het die ou pelagiaanse dwaling uit die vierde eeu in die remonstrantisme, in die opkomende metodisme en in die piëtisme herleef, in die sin dat die mens eers self die wil moet hê om gered te word - so asof die mens nie totaal in sy sonde verlore is nie.

Ds. Huet van die NG Kerk te Ladysmith in Natal meen dat die Gesange wat in 1814 vanuit Nederland ingevoer is, die brug was waaroor die liberalisme na ons kerke oorgestap het, en dat dit in 'n tyd plaasgevind het toe die gereformeerde leer nie meer op die kansels gehoor is nie (vgl. Spoelstra, 1963:50-51; Van der Vyver, 1959:13-27).

Teen hierdie rigtings, standpunte en strominge was daar reaksie. Veral in die noordoostelike deel van die ou Kaapkolonie was daar konserwatiewe trekboere wat in isolasie van die nuwe moderne rigting aan die Kaap gelewe het. Dit was mense wat hulle verryk het met die Statebybel met sy kanttekeninge, met die belydenisskrifte van die Reformasie, met 'n psalmboek en met geskrifte van teoloë uit die Nadere Reformasie, soos Comrie, à Brakel, Smijtegeld en andere. Vir die predikante van die Kaapse kerk, op 'n stadium vir meer as 50\% van Engelse afkoms, was hierdie konserwatiewe mense onverstaanbaar.

Hierdie mense het deel geword van die Groot Trek, en diegene wat voor die Groot Trek as trekboere met hulle vee reeds na die noordoostelike dele van Kaapland beweeg het, het ook later na die Vrystaat en Transvaal getrek. 
Spoelstra (1963) meen dat die Groot Trek van 1836, die stigting van die Boererepublieke van 1852 en 1854, die ontstaan van die onafhanklike Hervormde staatskerk van die Transvaalse republiek in 1853, asook die ontstaan van die Gereformeerde Kerk in 1859 iets in gemeen het: hulle wou die eiendomlike geestesbesit beskerm deur dit in isolasie te onttrek van 'n vreemde gees en 'n veranderde eeu; hulle wou vry wees. Om hierdie rede het die eerste gereformeerde kerk homself as 'n vrye kerk beskou, vry van inmenging van die staat, vry van menslike insettinge en vry om God te dien soos Hy dit verlang.

Op kerklik-godsdienstige terrein moet ons hulle protes teen die heersende kerkleer, die afwesigheid van die uitverkiesings- en verbondsprediking, die dwang om gesange te sing, die weerstand teen 'n kollegialistiese kerkregeringstelsel sien as 'n protes teen 'n humanistiese en liberalistiese eeu wat sy stempel vanuit die preekstoel, die liturgie en sinodes of ringe op gewone en eenvoudige gereformeerde mense wou afdruk.

Teen die middel van die 19de eeu het die weë dus geskei: daar was 'n afskeiding van 'n revivalistiese, metodistiese en piëtistiese godsdiens, ook van 'n modernistiese en rasionalistiese godsdiens.

\section{Die belangrikheid van die roeping tot die suiwer bediening van die Woord, sakramente en tug}

Wanneer die kerkgeskiedenis gedurende die tydperk 1836-1859 in die noordoostelike dele van die Kaapprovinsie, die suidelike dele van die Vrystaat en in Transvaal nagegaan word, is dit duidelik dat daar by heelwat lidmate 'n besondere behoefte aan suiwer gereformeerde bediening van die Woord, sakramente en kerkregering was.

In Bloemfontein het J.J. Venter - by tye waarnemende president van die Vrystaat - laat blyk dat hy probleme het met die prediking omdat dit na sy oordeel remonstrants was. Hy het 'n vurige begeerte na 'n werklike gereformeerde leraar gehad, en het selfs om hierdie rede 'n blanko beroepsbrief na Nederland gestuur. Hy was bereid om alle kostes daaraan verbonde, self te dra (vgl. D’Assonville, 1992:216).

In Transvaal, waar ds. Dirk van der Hoff die eerste predikant van die Hervormde staatskerk van die Republiek geword het, het daar gaandeweg 'n onrustigheid en ontevredenheid gekom. Paul Kruger, latere president van die Transvaalse republiek en een van die beswaardes teen die kerklike toestand, het sorg gedra dat die kerkraad van Rustenburg in 1857 asook die Volksraad toestemming gegee het dat die beswaardes 'n eie predikant binne die Hervormde staatskerk kan beroep 
(D’Assonville, 1992:220; Van der Vyver, 1959:14 e.v.). Op hierdie wyse is 'n kerkskeuring en onenigheid afgeweer.

'n Sekere J. van der Ryst van Calvinia (vroeër lidmaat van die Christelijke Afgeskeie Gereformeerde kerk te 's-Hertogenbosch) het in 'n brief aan ouderling J. van Andel van die kerk te 's-Hertogenbosch die behoefte aan 'n gereformeerde predikant vir lidmate in Transvaal goed verwoord, deur onder meer te stel dat hulle 'n geestelik behoefte daaraan het. lemand uit die Christelijke Afgeskeie Gereformeerde Kerk sal geskikter wees as nog 'n predikant uit die Hervormde kerk van Nederland, volgens broeder Van der Ryst. So het die nood van 'n predikant op die tafel van die betrokke kerk se sinode van 1857 te Leiden gekom (vgl. Van der Vyver, 1959:14-15).

Toe ds. D. Postma eindelik hierheen gekom het, was dit duidelik dat die skeiding op verskillende plekke alreeds bestaan het, en nadat hy as predikant van die eerste Gereformeerde kerk te Rustenburg bevestig is, het daar in bepaalde streke van Transvaal, die Vrystaat en NoordoosKaap, spoedig Gereformeerde kerke ontstaan.

\subsection{Teologiese opleiding}

Daar was heelwat pogings om nog predikante vanuit Nederland te beroep, maar slegs een predikant, naamlik ds. J. Beyer, het die beroep aanvaar. Die enigste uitweg was om met 'n eie teologiese opleiding te begin. Aanvanklik - in die periode vanaf 1863 tot 1869 - is predikante aan huis van di. Postma en Beyer opgelei, maar in 1869 is besluit om 'n eie Teologiese Skool te Burgersdorp op te rig (vgl. Jooste, 1959:98-109).

In die besluit van die Sinode van 1869 om 'n eie Teologiese Skool op te rig, is dit duidelik gestel dat ook studente wat hulle as onderwysers of vir ander beroepe wil laat oplei, kan aanmeld.

Uit hierdie Skool het 'n universiteit gegroei: in 1876 is die literariese afdeling van die Teologiese Skool deegliker onderskei; in 1904 is die Skool en literariese afdeling na Potchefstroom verskuif; in 1918-1920 is die Potchefstroomse Universiteitskollege soos enkele ander soortgelyke kolleges as een van die samestellende kolleges by die Universiteit van Suid-Afrika geïnkorporeer, en in 1951 het die Potchefstroomse Universiteit vir $\mathrm{CHO}$ wetlik sy selfstandigheid as Christelike universiteit ontvang (vgl. oorsig van Coetzee, 1959:225-244; Reinecke, 1998:181-222).

Tussen die Teologiese Skool van die Gereformeerde Kerke in SuidAfrika en die PU vir CHO bestaan daar sedert 1945 'n kontraktuele ooreenkoms waarvolgens elke inrigting se selfstandigheid erken word, 
wat aandui hoe teologiese professore beroep en benoem word vir albei inrigtings, ensovoorts.

\subsection{Die Gereformeerde Kerke in Suid-Afrika en die PU vir CHO}

Hoewel dit duidelik gestel moet word dat die PU vir $\mathrm{CHO}$ 'n eie selfstandige en volwaardige universiteit is, en derhalwe nie kerklik beheer word nie, is dit wel waar dat historiese en resente aandrang op die behoud van sy Christelike karakter toegeskryf kan word aan 'n gereformeerde standpunt oor onderwys as sodanig. Dit hang nou saam met artikel 21 van die kerkorde van die Gereformeerde Kerke wat Christelike onderrig voorskryf.

Die kerkorde verwoord 'n beginsel oor die onderwys, naamlik dat kerke sal toesien dat onderwys in die vrees van die Here sal geskied. Dit impliseer nie dat die kerke self die onderwys moet behartig nie, maar wel dat hulle 'n verantwoordelikheid het om toe te sien dat dit gebeur.

Gereformeerde mense soos prof. Jan Lion Cachet het reeds in 1889 in 'n rede by die Teologiese Skool daarop gewys dat die hele wetenskap in die lig van die Woord beoefen moet word, en in 1911 het hy by sy afskeid gesê dat die gedagte van 'n Christelike universiteit van die begin af die ideaal was by die oprigters van die Teologiese Skool (Van Rooy, 1998:91).

Nadat Totius en dr. F. Postma aan die begin van die 20ste eeu vanuit Nederland, teruggekeer het, na die voltooing van hul doktorsgrade aan die Vrije Universiteit van Amsterdam, was hulle besiel met die gedagte van 'n eie volwaardige Christelike universteit in ons land. Dit sou ook kon meehelp om die volk na die verwoestende Tweede Vryheidsoorlog op te hef (Van Rooy, 1998:92).

Christelike onderwys - ook op tersiêre vlak - oftewel Christelike wetenskap is nie 'n ander soort wetenskap nie. Dit is wetenskapsbeoefening op Christelike grondslag. Die vertrekpunt is vanuit die koninkryk van God, waarvolgens aanvaar word dat God in Christus oor alles regeer. Daar kan dus geen terrein van die lewe of werklikheid wees wat nie binne die regering en beheer van God self bestaan nie. Die Christelike wetenskaplike verwerp die gedagte van 'n dualisme tussen geloof en wetenskap.

Soos enige wetenskaplike vra die Christelike wetenskaplike vakfilosofiese vrae, maar neem as vertrekpunt die geloof in God wat alles geskape het en alles onderhou. Hy moet juis hierdie perspektiewe in die wetenskap navors, en eindelik verwonderd staan oor die wonder van God se skepping. Die Woord van God bied aan hom die raamwerk of 
ruimte waarbinne hy met sy wetenskap moet besig wees, in die sin dat die Woord van God byvoorbeeld die norme of waardes of beginsels gee, soos respek vir lewe en 'n etiese waardesisteem (vgl. Du Plooy, 2001: 35-45).

Aan die PU vir $\mathrm{CHO}$ is in die dertigerjare 'n eie Fakulteit Teologie verkry. Die Fakulteit Teologie werk in terme van die genoemde ooreenkoms nou met die Gereformeerde Kerke saam om byvoorbeeld graadkursusse aan te bied vir studente wat hulle as predikante wil bekwaam. Hierbenewens bied dit ook ander akademiese pakkette en grade aan vir alle belangstellendes in teologie, ongeag kerkverband.

Die Fakulteit Teologie het 'n uitgesproke gereformeerde tradisie en stel hom onder meer ten doel, aangesien dit as sy roeping geag word, om die gereformeerde teologie binnelands en buitelands aan soveel moontlik inrigtings beskikbaar te stel. Tans is daar reeds 13 teologiese kolleges en inrigtings (nege binnelands en vier buitelands) wat as geakkrediteerde inrigtings van die Fakulteit Teologie bekend staan, en wat in terme van onderlinge ooreenkomste teologiese graadkursusse van die $\mathrm{PU}$ vir $\mathrm{CHO}$ aanbied.

\section{Die roeping tot eenheid}

Die koninkryk van God is as sodanig een van die belangrikste motiewe vir die eenheid van die kerk. Onder die koninkryk van God kan primêr verstaan word dat God regeer en dat Hy soewerein is (Van der Walt, 1962:33; 1969:99). Die grondliggende gedagte van die koninkryk van God is dat Hy in Christus Koning is en Hoof van die ganse skepping, en in besonder Hoof van die kerk as sy liggaam.

Daar is slegs een koninkryk van God wat gekom het, besig is om te kom en wat eendag in sy volheid sal kom; en die prediking van die koninkryk van God het een kerk tot gevolg. Die kerk as die volk van God het wêreldwyd slegs een Koning, en die onderdane van die koninkryk beërf een en dieselfde koninkryk. Erfgename is niks anders as broers en susters nie. Christus as Koning en Hoof het in die kerk slegs een liggaam in wie die een Gees van God kom woon het.

Hierdie ou gereformeerde visie is in die tweede helfte van die $20 \mathrm{e}$ eeu as 't ware nuut ontdek, en dit het tot gevolg gehad dat gereformeerdes wêreldwyd hulle weer beywer het vir die sigbare eenheid van 'n versplinterde kerk van Christus. Die Gereformeerde Kerke in Suid-Afrika het hulle met groot erns hieraan toegewy. 'n Groot deel van die aktiwiteite van die Gereformeerde Kerke is gedurende hierdie tydperk hieraan bestee. 


\subsection{Eenheid tussen die drie Afrikaanse Kerkgemeenskappe}

$\mathrm{Na}$ die ontstaan van die Gereformeerde Kerke in Suid-Afrika in 1859 en daarna was daar geen vaste onderlinge verhoudinge tussen die kerkgemeenskappe nie. Jooste (1958:67 e.v.) beskryf die versoeningspogings wat daarna gekom het, en toon aan dat dit tot niks konkreets gelei het nie.

Die Eerste en Tweede Vryheidsoorloë het wel as 'n stimulus gedien om die kerkgemeenskappe nader aan mekaar te bring, en in die verloop van die eerste helfte van die 20ste eeu was daar insidentele pogings om die drie kerkgemeenskappe nader aan mekaar te bring (vgl. Jooste, 1958: 370-380).

Die jaar 1958 was die jaar waarin op aandrang van 'n interkerklike kommissie van die drie kerkgemeenskappe ooreengekom is dat 'n ander vorm van verband tussen die drie kerkgemeenskappe gesoek moet word, naamlik in die vorm van 'n broederlike gesprek (GKSA, 1958:77).

Die GKSA het toe die prinsipiële standpunt ingeneem dat die bestaan van drie gereformeerde kerkgemeenskappe in een land, met dieselfde belydenis, taal en kultuur, ' $n$ sondige geskeidenheid is, en nie in terme van Kuyper se pluriformiteitsbeskouing as 'n aanvaarbare verskeidenheid beskou kan word nie. Die gesprekke het plaasvind in die Tussenkerklike Kommissie, waarin elke kerkgemeenskap deur 'n willekeurige aantal lede verteenwoordig is.

Sedertdien is daar by wyse van verskillende memoranda broederlike gesprekke gevoer tussen die drie gemeenskappe. Soms is ook bilaterale gesprekke gevoer, maar in die reël is tussen die drie groepe deputate (of kommissies) gepoog om verskilpunte te identifiseer en te evalueer. Mettertyd is meer op punte van ooreenstemming gekonsentreer, en gaandeweg is terreine van samewerking bepaal en ontgin.

Die GKSA beskou dit as 'n roeping, kragtens die belydenis van die eenheid van die kerk, om naas samewerking op vele vlakke nie te berus in die sondige geskeidenheid van die kerk van Christus nie, maar om voort te gaan om ook sigbaar te word wat ware kerke van Christus in Christus is en behoort te wees.

\subsection{Ekumenisiteit}

Die gedagte van 'n ekumeniese sinode is in 1924 tydens die sinode te Rustenburg die eerste keer deur prof. H.H. Kuyper uitgespreek toe hy die sinode toegespreek het. Dit het daartoe gelei dat die Gereformeerde Kerke in Suid-Afrika die inisiatief geneem het. 
In die Handelinge van die eerste Ekumeniese Sinode van 1946 te Grand Rapids staan die volgende geskryf:

In 1924, at the synod of Rustenburg in Transvaal Die Gereformeerde Kerk in Suid-Afrika started a movement which aimed at the calling of an ecumenical synod ... In August 1946 at the first reformed Ecumenical Synod met at Grand Rapids, Michigan (RES, 1946).

Die behoefte aan motivering hiervoor was die toepassing van artikel 30 van die kerkorde waar onder meer gestel word dat kerke mekaar in die kerkregering moet bystaan indien sake nie in 'n mindere vergadering afgehandel kan word nie, of wanneer kerke oor gemeenskaplike sake moet handel. Daar is gevoel dat die gereformeerde kerke oor die wêreld heelwat sake en probleme gemeen het, en mekaar derhalwe in 'n werklike ekumeniese vergadering moet bystaan (vgl. Jooste, 1959:118119).

Die GKSA het deel gebly van die GES tot in 1988. Terloops, in 1988 het die naam van die GES na die Gereformeerde Ekumeniese Raad (GER) verander.

Die vernaamste redes waarom die GKSA en ook enkele ander kerkgemeenskappe uit die GER getree het, is die volgende: die dubbele lidmaatskap van sommige lidkerke, naamlik by die GER sowel as by die Wêreldraad van Kerke; die onhoudbare teologiese standpunte van een van die lidkerke, naamlik die Gereformeerde Kerken Nederland, veral oor Skrifgesag en oor homoseksualiteit (GKSA, 1991:153 e.v.).

Ten spyte van die teenspoed met die GER is die GKSA oortuig dat ekumenisiteit nie net langs die weg van ekumeniese liggame beoefen hoef te word nie, aangesien die algemeenheid, oftewel die katolisiteit en ekumenisiteit van die kerk as een van sy wesenseienskappe, voortdurend en op verskillende maniere belewe moet word. Dit hang saam met die begrip kerklike korrespondensie. Die GKSA het in 1967 en ook weer in 2000 tydens nasionale sinodes ernstig oor die roeping en konkrete metodes van ekumenisiteit nagedink en besluit. In 2000 (GKSA, 2000:210) is besluit om drie fases, of drie sirkels in die beoefening van ekumenisiteit te onderskei, naamlik:

- Ekumeniese eenheid. Dit is werklike kerkeenheid of kerklike korrespondensie in die ware sin met kerke in ander dele van die ekumene (of wêreld).

- Ekumeniese bande. Dit beskryf die samewerking met die oog op moontlike eenheid. 
- Ekumeniese kontak. Dit beskryf die gesprekke met kerkgemeenskappe met wie daar vanuit die belydenisgrondslag minder gemeenskaplik is, maar met wie moontlik gevorder kan word in die rigting van groter eenheid, samewerking en gesamentlike getuienis.

Ten opsigte van al drie verhoudings is die GKSA besonder aktief, en word daar in die binneland (soos onder meer in die gereelde vergadering van die Reformatoriese Konvent), asook in die buiteland, afgevaardigdes gestuur na verskillende kerkgemeenskappe.

\subsection{Sending en kerkeenheid oor volks- en taalgrense heen}

Aanvanklik, na die ontstaan van die GKSA in 1859, is weinig aan direkte en georganiseerde sendingwerk gedoen. Prof. Hugo du Plessis, bekende Gereformeerde missioloog, noem twee redes hiervoor (Du Plessis, 1959:121):

- Die stryd vir die jong en arm kerke na 1859 om self die mas op te kom, was veeleisend.

- Die boeremense se assosiasie met sending en sendelinge was besonder negatief. Die sending waarmee die Voortrekkers bekend was, was negrofilisties en filantropies inhoudelik sterk beïnvloed deur die piëtisme, en Du Plessis voeg by dat dit 'n sending was met 'n "denasionaliserende sendingmetode en op die spits gedrewe gelykstelling".

Die GKSA het ten spyte hiervan, van die eerste sinodes af (byvoorbeeld in besonder in 1869 en 1973) sterk prinsipieel besin oor die sendingtaak van die kerk van Christus. Die eerste sendingleraar wat die Gereformeerde Kerke (kerkraad van Pretoria) uitgestuur het, was ds. P. Bos, in 1910. Hy moes in die distrik Soutpansberg gaan sendingwerk doen.

Van toe af het die sendingwerk van gereformeerde kerke sterk momentum verkry. (Vir 'n oorsig hieroor kan verwys word na Du Plessis, 1959:121-131; Jooste, 1958:323-351; Van Rooy, 1995:221-240; Spoelstra, 1999.)

Jooste (1958:351) skryf dat 'n klassis van selfstandige kerke onder die swart volke vir die eerste keer in 1957 vergader het, en dat toe gedink is aan die vorming van 'n selfstandige kerkverband vir kerke wat uit die sending selfstandig word.

Die GKSA het sedertdien, namate daar 'n toename in die geledere van die sogenaamde "jong kerke" gekom het, ernstig besin oor die strukturele wyse van eenheid en gesamentlike vergadering in meerdere 
vergaderings (vgl. Du Plooy, 1986:38-49; Du Plessis, Coetzee, Du Toit e.a., 1961:7-75).

In 1961 (GKSA, 1961:115-119) is besluit om op kerklike gebied ras- en volksvermenging as beginsel en reël te verwerp. Kerke (plaaslik) moet hulle binne nasionale verbande - etnies en talig - tot op nasionale vlak organiseer.

In die periode 1958-1966 het die Algemene Sinode ontstaan, en in 1966 vir die eerste keer vergader. Hierheen het die sinodes van die verskillende nasionale groepe, naamlik Sinodes Potchefstroom, Middellande (hoofsaaklik Nguni- en Sothosprekendes), Soutpansberg (Vendas) en Suidland (kleurlinge) 'n gelyke getal afgevaardigdes gestuur. Teen 1990 het die Sinode Suidland besluit om nie meer afsonderlik te vergader nie, en het die kerke onder die kleurlinge gewoon ingeskakel by die naby geleë kerke wat Sinode Potchefstroom saamstel (vgl. GKSA, 1991:530-532).

Sedert 1988 het die Algemene Sinode nog nie vergader nie, aangesien Sinodes Soutpansberg en Middellande van oortuiging is dat meerdere vergaderings slegs geografies gestruktureer moet word, en dat taal en etnisiteit nie in ag geneem moet word nie.

In terme van artikel 48 van die kerkorde vind daar van tyd tot tyd indringende gesprek hieroor plaas, en is 'n model op die tafel waarvolgens meerdere vergaderings slegs op geografiese of streeksbasis gestruktureer word. Hiervolgens het kerke wat met mekaar op kerklike terrein iets in besonder gemeen het, die reg om van tyd tot tyd in meerdere vergaderings saam te vergader (vgl. GKSA, 2000:497-501). (Met die uitdrukking "op kerklike terrein iets gemeen het", word veral taalgemeenskaplikheid bedoel. Solank daar ' $n$ behoefte is om op grond hiervan te vergader - in terme van artikel 30 van die Kerkorde - het kerke die reg daartoe.)

Die werklike eenheid tussen kerke oor die grense van taal en etnisiteit is vir al die gereformeerde kerke in Suidelike Afrika 'n belangrike saak. 'n Groot stap vorentoe is gevorder toe al drie Nasionale Sinodes in 1994 besluit het om die teologiese opleiding van studente aan een teologiese skool te Potchefstroom te laat plaasvind. Sedert 1995 is die opleiding geïntegreer, en studeer alle studente wat hulle as predikante in 'n gereformeerde kerk wil laat bekwaam aan die Teologiese Skool Potchefstroom. Die Fakulteit Teologie en die Teologiese Skool is besig om swart dosente in te faseer en te betrek by die opleiding van predikante. 


\section{Die roeping tot geregtigheid in die samelewing; die GKSA en die ideologie van apartheid}

Net soos die geval met die Nederduitse Gereformeerde en die Nederduitsch Hervormde Kerke is die Gereformeerde Kerke in Suid-Afrika veral gedurende die tweede helfte van die 20ste eeu skerp gekritiseer en verwyt vir hulle beweerde steun vir apartheid of vir die gebrekkige konstruktiewe verwerping en uitwissing daarvan.

Die kernprobleem met 'n ideologie van apartheid, soos dit nie net op 'n gewone verhoudingsvlak tussen mense gebeur het nie, maar ook juridies gestalte gekry het, is dat dit mense veronreg het en dat dit dade van ongeregtigheid is (vgl. hieroor 'n teologiese en juridiese perspektief van Vorster, 2002:69 e.v.).

Die vraag is derhalwe wat die GKSA se standpunte en optrede in hierdie verband is en was, gesien die roeping van die kerk om geregtigheid te laat geskied en getuienis in belang van geregtigheid te lewer.

Weereens sal slegs enkele tendense en besluite kursories aangedui word. Drie tydperke sal kortliks aan die orde kom: die situasie by die oorgang van die 19de na die 20ste eeu; die ontwikkeling tot 1958; die tydperk vanaf 1961 tot op hede.

\subsection{Die situasie by die oorgang van die 19de na die 20ste eeu}

Die Grondwet van die Zuid-Afrikaansche Republiek van 1852 het in artikel 9 bepaal dat die volk geen gelykstelling van gekeurdes met blankes toestaan nie, sowel in die kerk as in die staat.

Toe die sinode van 1869 (GKSA, 1869:24) oor die verhouding tussen blankes en gekleurdes gehandel het, het die sinode selfstandig op sy eie geoordeel dat gelykstelling tot op daardie tydstip nie gepas was nie, maar dat dit 'n ideaal is in terme van Genesis 22:18, Psalm 67 en 87. Verder is gestel dat die sinode graag in die rigting wil werk in die lig van die bevel van die Here volgens Matteus 28:19 en Markus 16:15.

In hierdie vroeë tydperk het die GKSA voortgegaan met afsonderlike dienste en is gemengde huwelike as onbetaamlik beskou (GKSA, 1873:32-33; 1891:38).

Na die Anglo-Boereoorlog (1899-1902), en met Uniewording is die beleid van segregasie, soos in die meeste Britse kolonies, voortgesit (Kinghorn, 1986:1). 


\subsection{Die ontwikkeling tot 1958}

Die Afrikanervolk waarvan 'n groot persentasie lidmate was van een van die drie Afrikaanse kerkgemeenskappe, het gedurende hierdie tydperk 'n tyd van ontwaking en ontwikkeling belewe: daar was die stryd vir 'n eie republiek, vir taalregte, vir eie skole, vir 'n eie Bybelvertaling ens. So het daar 'n sterk gevoel van nasionalisme bestaan, byvoorbeeld rondom die ingebruikneming van die Voortrekkermonument in 1949, en tydens goed georganiseerde volksfeeste.

Kerklike figure, waaronder byvoorbeeld J.D. du Toit, of Totius (1977) was dikwels ook groot volksmanne en leiers in die samelewing. Tydens die Volkskongres van 1944 het Totius probeer om 'n godsdienstige grondslag vir die rassebeleid van segregasie te gee. Die beleid van apartheid is verdedig vanuit die Bybelse skeppingsmotief waar God as die groot Skeidingmaker beklemtoon word, en vanuit die Babelmotief waar God die mens in 'n veelheid van nasies uitmekaar laat gaan het.

Teen hierdie agtergrond neem die Nasionale Sinode (GKSA, 1958:265270) na aanleiding van ' $n$ indringende rapport oor rasseverhoudings in die lig van die Skrif twee interessante besluite:

- Aan die een kant oordeel die sinode dat rassevermenging op kerklike terrein ongeoorloof is, uit vrees vir die ondermyning van die nasionale identiteit en die getalswakkere blankes.

- Aan die ander kant besluit die sinode dat die krenkende rassediskriminasie gaandeweg opgehef moet word, en dat die verskillende gemeenskappe in die land ook die geleentheid moet kry om oor gemeenskaplike belange saam te verkeer.

In hierdie tyd het die bekende publikasie, Uit een bloed (Du Plessis et al., 1961:7-75), verskyn. Dit handel insiggewend oor die standpunte van prominente teoloë, regsgeleerdes en volkekundiges in die Gereformeerde Kerke in Suid-Afrika, en gee 'n goeie oorsig oor hul eie sienings, asook oor die besluite van die sinodes van die Gereformeerde Kerke oor rasse- en volkeverhoudings tot op daardie stadium.

\subsection{Die periode vanaf 1961 tot op hede}

Gedurende hierdie tyd is besondere aandag gegee aan volkereverhoudings, in sowel die kerk as die samelewing. Dit was die periode waarin byvoorbeeld die Algemene Sinode tot stand gekom het, waaroor vroeër reeds gehandel is.

In 1970 (GKSA, 1970:62) het die sinode 'n maatskaplik-politieke beleid verkies wat op gebiedskeiding neerkom. 
In 1985 het die sinode (GKSA, 1985:426 e.v.) 'n lywige rapport behandel waarin alle besluite van die verlede waarin oor rasse- en volkereverhoudings in die kerk en in die samelewing gehandel is, in heroorweging geneem is.

Die resultaat hiervan was onder meer die volgende:

- Die besluit oor gebiedskeiding van 1970 is herroep.

- 'n Aansporing tot skuldbelydenis deur Christene oor die verskeurdheid en sondige skeiding en houding tussen mense (soos reeds in 1970 GKSA, 1970:63 besluit) is herhaal.

- 'n Bewoëndheid teenoor armes en polities verdruktes word uitgespreek, en pertinent word besluit: "Elke vorm van rasseheerskappy en rassisme is te verwerp" (GKSA, 1985:439/443).

- Huwelike oor kleurgrense heen kan in die lig van die Skrif nie as sondig of ongeoorloof verklaar word nie.

- Ten opsigte van die vraagstuk van 'n beleid vir tuislande, oordeel die sinode soos volg:

Waar 'n toestand van algehele gebiedskeiding om talle redes (onder andere geografiese en ekonomiese) nie moontlik is nie, word 'n besonder groot verantwoordelikheid op volke en bevolkingsgroepe geplaas om onderling in ' $n$ gesindheid van vrede, vryheid, versoening en regverdigheid saam te lewe, sodat die regte van minderhede geëerbiedig word en oorheersing uitgeskakel word (GKSA, 1985:444).

Ten opsigte van die beleid van apartheid het die sinode van 1991, (GKSA, 1991:160/169) in die lig van die standpunt tydens die GES te Harare in 1988, besluit dat "die ideologie van apartheid 'n sonde en die Bybelse regverdiging daarvan 'n dwaling is". Die volledige Engelse teks soos in Harare voorgedra, lui soos volg:

The ideology of apartheid, which is a political and social system by which human dignity is adversely affected and whereby one particular group is detrimentally suppressed by another, cannot be accepted on Christian grounds because it contravenes the very essence of reconciliation, neighbourly love and righteousness, the unity of the Church and inevitably the human dignity of all involved and it is therefore a sin and the biblical justification a heresy.

Ten opsigte van die aandrang en versoek by wyse van 'n beskrywingspunt aan die Nasionale Sinode in 1997 (GKSA, 1997:884-885) dat die GKSA in die Nasionale Sinode hom moet verantwoord oor 'n moontlike aanspreeklikheid vir die staatkundig-sosiale verlede met be- 
trekking tot die beleid van apartheid, het die sinode hom nie oor die regmatigheid al dan nie van skuld en van 'n skuldbelydenis uitgespreek nie.

Die vernaamste rede daarvoor was die gebrekkige inligting wat beskikbaar was en die feit dat daar geen gegewens was oor direkte besluite waaroor die sinode dan 'n besluit sou moes neem nie.

By wyse van retrospeksie, en met inagneming van die werklikhede van die verlede, lyk dit of die GKSA die ideologie van apartheid en die onreg wat dit meegebring het, nie genoegsaam en effektief bestry het nie, en dus in gebreke gebly het om werklik aktief mee te werk aan die vernietiging daarvan.

\section{Roeping tot getuienis in die samelewing}

Ten opsigte van die betrokkenheid van die GKSA in die samelewing was daar altyd op grond van die formulering in artikel 30 van die kerkorde (naamlik dat kerklike vergaderinge alleen kerklike sake op kerklike wyse moet behandel) 'n huiwerende terughoudendheid om direk betrokke te raak by maatskaplike, politieke, onderwys- of ander sogenaamde niekerklike aangeleenthede.

Die sinode van 1942 (GKSA, 1942:25) het in 'n interpretasie daarvan gestel dat die formulering histories verstaan moet word, en nie in absolute sin geïnterpreteer moet word nie. Die kerk is geroep om die lig van die Woord oor alle terreine van die lewe te laat uitstraal (vgl. Vorster, 1996:179-196).

Dit lyk beter om die getuienis en betrokkenheid van die kerk in die samelewing vanuit 'n koninkryksperspektief te beskou. Dit beteken dat Christus Koning is oor alles en almal, en dat die kerk instrumenteel geroep is om die lig van die Woord oor alles waaroor die Woord van God iets openbaar of leer te verkondig of daaroor te getuig, ongeag waaroor die saak of onderwerp handel.

Dit lyk asof die GKSA ten opsigte van sy taak en roeping na buite, in die samelewing, nie genoegsaam getuienis gelewer het nie, waarskynlik omdat (dikwels met goeie reg) 'n versigtige benadering gelei het tot ' $n$ na binne kerklik-institutêre betrokkenheid. Dit bly natuurlik waar dat in die Calvinistiese tradisie 'n duidelike onderskeiding tussen die terrein van byvoorbeeld die kerk en die owerheid bestaan, hoewel die kerk te alle tye sy eiesoortige roeping en taak tot getuienislewering het.

In hierdie verband is dit ook die standpunt van die GKSA dat getuienis in en teenoor die owerheid en/of die samelewing nie slegs die taak van 
meerdere vergaderings is nie, maar in terme van artikel 28 van die kerkorde ook die verantwoordelikheid van elke plaaslike kerk is. Die plaaslike kerk is immers volledig en selfstandig kerk van Christus. Hierbenewens is dit ook die amp van die professore in teologie (in terme van artikel 18 van die kerkorde) om vanuit die Woord en die konfessie getuienis téén dwalings en vír die waarheid te lewer.

So is daar byvoorbeeld deur die professore van die Teologiese Skool 'n sogenaamde "Hervormingsdaggetuienis" op 31 Oktober 2000 in die openbaar gelewer (vgl. Van Wyk, 2001:159-164). Hierdie getuienis het gehandel oor kernleerstukke van die Christelike geloof, en oor ernstige morele sake.

Die vernaamste motiverings vir die getuienis was dat:

- die gesag en betroubaarheid van die Bybel in gedrang is;

- die liggaamlike opstanding van Jesus Christus bevraagteken word;

- die samelewing deur skokkende morele vergrype geteister word;

- sommige gelowiges begin om moedeloos en verward te word.

\section{Bestek}

Waar 2002 die jaar was waarin die 350 jaar gereformeerd-wees herdenk is, is dit belangrik dat ook die Gereformeerde Kerke in Suid-Afrika 'n terugskouing oor die geskiedenis moet maak. Hierdie artikel het probeer om enkele aspekte te belig.

Ons is deel van die tradisie van gereformeerde kerke, en in hierdie sin is daar vir elke kerkgemeenskap kontinue en diskontinue lyne ten opsigte van die geskiedenis. Sommige kerkgemeenskappe se geskiedenis gaan direk terug tot by die Reformasie, ander op indirekte wyse, maar per slot van rekening is 'n ware gereformeerde kerk in terme van die konfessie 'n apostoliese kerk, en het dit 'n direkte band met die leer van die apostels in hulle verbondenheid aan Jesus Christus.

Hoewel die kerk die verloste volk van God in Christus is, is dit steeds sondig en onvolmaak. So is ook die GKSA vol gebreke en onvolmaak omdat dit uit sondige mense bestaan. Tog is ons seker van al die weldade van God in Christus deur die Woord van God en die werk van die Heilige Gees in ons harte.

Die GKSA het hom in die verlede - vir die 143 jaar wat hy as afsonderlike gereformeerde kerkverband bestaan - probeer beywer vir die waarheid en gesag van die Woord van God, vir die eenheid van die kerk omdat dit deel is van die waarheid en vir geregtigheid, en steeds sal dit 
die taak en roeping van die kerk moet bly. Ons is oortuig dat die kerk veral geroep is om die merktekens van die ware kerk, naamlik die suiwer verkondiging en aanhoor van die Woord, die bediening van die sakramente en die bediening van die kerklike dissipline of tug, met ywer en toewyding te beoefen.

Die positiewe opmerking is sekerlik geregverdig, naamlik dat die Gereformeerde Kerke in Suid-Afrika in sowel die kerklike lewe as in die samelewing 'n besondere bydrae gelewer het om vanuit die Skrif en ons Reformatoriese tradisie prinsipiële grondslae of riglyne te gee. Hierdie grondslae en riglyne het die Kerk in staat gestel om krities en nuutskeppend na die verhoudingsproblematiek en na knelpunte in die samelewing wat besonderlik deur apartheid en afsonderlikheid teweeggebring is, te probeer oplos.

Die realiteit is egter ook dat hierdie proses nog nie voltooi is nie, en dat terugskouend op die geskiedenis van die Gereformeerde Kerke in SuidAfrika - veral dan oor die laatse vyftig jaar - gesê moet word dat daar nie genoeg gedoen is nie. Daar is byvoorbeeld nie genoeg gedoen om die ideologie van apartheid en al die negatiewe gevolge en implikasies daarvan daadwerklik tot ' $n$ einde te help bring nie. Daar kon ook meer gedoen gewees het om die sigbare eenheid en eenheidsbelewing tussen die verskillende gereformeerde kerke onder die volks- en taalgemeenskappe in ons land konstruktief en beter gestalte te laat kry het.

Mag God steeds sy kerk - ook die Gereformeerde Kerke in Suid-Afrika as sy dienskneg gebruik om die evangelie van die koninkryk van God tot opbou van die kerk van Christus en tot heil en seën van die samelewing te verkondig.

\section{Bibliografie}

COETZEE, J.C. 1959. Die Gereformeerde Kerk en die Christelike Hoër Onderwys. (In Du Toit, S., red. Die Gereformeerde Kerk in Suid-Afrika 1859-1959. Gedenkboek by geleentheid van die eeufees. Johannesburg : Dagbreekpers. p. 225-244.)

D'ASSONVILLE, V.E. 1992. Gids vir kerkgeskiedenis. Potchefstroom : Marnix.

DU PLESSIS, H. 1959. Die Gereformeerde Kerk en die sending. (In Du Toit, S., red. Die Gereformeerde Kerk in Suid-Afrika 1859-1959. Gedenkboek by geleentheid van die eeufees. Johannesburg : Dagbreekpers. p. 121-131.)

DU PLESSIS, L.J., COETZEE, J.H., DU TOIT, S., SNYMAN, W.J., DU PLESSIS H. \& LOMBARD, B.J. 1961. Uit een bloed. Rapport aan en 'n besluit van die algemene sinode van die Gereformeerde Kerke in Suid-Afrika oor rasseverhoudinge. Potchefstroom : Pro Rege. 
DU PLOOY, A. LE R. 1986. Besinning oor eenheid in kerkverband oor nasionale en taalgrense. (In Smit, C.J., red. In gehoorsaamheid: opstelbundel aangebied aan prof. dr. G.P.L. van der Linde by sy emeritering as hoogleraar. Potchefstroom : PTP. p. 32-49.)

DU PLOOY, A. LE R. 2001. Koninkryk, kerk en universiteit. (In Van Wyk, J.H., red. Kerk- en Christenwees vandag. Potchefstroom : PTP. p. 35-45.)

DU TOIT, J.D. 1903. Het Methodisme. Pretoria : Hoveker \& Wormser.

DU TOIT, J.D. 1977. Totius. Versamelde Werke. Deel 7. Kaapstad : Tafelberg.

GEREFORMEERDE KERKE IN SUID-AFRIKA. 1869. Handelingen van de $4 e$ algemene synodale kerkvergadering van de Gereformeerde gemeenten van Zuid-Afrika. Kaapstad : Saul Solomon.

GEREFORMEERDE KERKE IN SUID-AFRIKA. 1873. Handelingen van de 5e algemene synodale kerkvergadering van de Gereformeerde gemeenten van Zuid-Afrika. Kaapstad : Saul Solomon.

GEREFORMEERDE KERKE IN SUID-AFRIKA. 1891. Handelingen van de 11e algemene synodale kerkvergadering van de Gereformeerde gemeenten van Zuid-Afrika. Paarl : D.F. du Toit.

GEREFORMEERDE KERKE IN SUID-AFRIKA. 1942. Handelinge van die 27e sinodale vergadering van die Gereformeerde gemeentes in Suid-Afrika. Potchefstroom : Herald.

GEREFORMEERDE KERKE IN SUID-AFRIKA. 1958. Handelinge van die 33ste sinodale vergadering van die Gereformeerde Kerk in Suid-Afrika. Potchefstroom : Herald.

GEREFORMEERDE KERKE IN SUID-AFRIKA. 1961. Handelinge van die 34ste sinodale vergadering van die Gereformeerde Kerke in Suid-Afrika. Potchefstroom : Herald.

GEREFORMEERDE KERKE IN SUID-AFRIKA. 1970. Handelinge van die 37ste sinodale vergadering van die Gereformeerde Kerke in Suid-Afrika. Potchefstroom : Herald.

GEREFORMEERDE KERKE IN SUID-AFRIKA. 1985. Handelinge van die 42ste Nasionale Sinode te Potchefstroom. Potchefstroom : Herald.

GEREFORMEERDE KERKE IN SUID-AFRIKA. 1991. Handelinge van die 44ste Nasionale Sinode te Potchefstroom. Potchefstroom : Herald.

GEREFORMEERDE KERKE IN SUID-AFRIKA. 1997. Handelinge van die 46ste Nasionale Sinode te Potchefstroom. Pretoria : V\&R.

GEREFORMEERDE KERKE IN SUID-AFRIKA. 2000. Handelinge van die 47ste GKSA Nasionale Sinode te Potchefstroom. Potchefstroom : Herald.

kyk GEREFORMEERDE KERKE IN SUID-AFRIKA

HANEKOM, T.N. 1951. Die liberale rigting in Suid-Afrika, deel 1. Stellenbosch : CSV.

JOOSTE, J.P. 1958. Die geskiedenis van die Gereformeerde Kerk in Suid-Afrika 1859-1959. Potchefstroom : Herald.

JOOSTE, J.P. 1959. Die ontstaan en geskiedenis van die Teologiese Skool. (In Du Toit, S., red. Die Gereformeerde Kerk in Suid-Afrika 1859-1959. Gedenkboek by geleentheid van die eeufees. Johannesburg : Dagbreekpers. p. 98-109.)

KINGHORN, J., red. 1986. Die NG Kerk en apartheid. Braamfontein : Macmillan.

REFORMED ECUMENICAL SYNOD. 1946. Acts of the first reformed Ecumenical Synod in session from August 14 to August 30, 1946. Grand Rapids : Eerdmans. 
REINECKE, C.J. 1998. Die wording van die PU vir $\mathrm{CHO}$ as deel van die SuidAfrikaanse universiteitsisteem. (In KOERS. Verkennings in oorgang. Gedagtes by die 125-jarige bestaansjaar van die PU vir CHO - 1994. Supplement 1.

RES Orkney : EFJS. p. 181-222.)

kyk REFORMED ECUMENICAL SYNOD

SPOELSTRA, B. 1963. Die Doppers in Suid-Afrika 1760-1899. Johannesburg : Nasionale Boekhandel.

SPOELSTRA, B. 1999. Sending vir kerk of koninkryk? Sendinggeskiedenis van die GKSA 1869-1994. Potchefstroom : PTP.

VAN DER WALT, T. 1962. Die koninkryk van God naby! Kampen : Kok.

VAN DER WALT, T. 1969. Die voleinding van die koninkryk. (In Du Toit, S.. red. Die koninkryk van God. Potchefstroom : Herald. p. 96-109.)

VAN DER VYVER, G.C.P. 1959. Ds. Dirk Postma - God voorsien in 'n uur van nood. (In Du Toit, S., red. Die Gereformeerde Kerk in Suid-Afrika 1859-1959. Gedenkboek by geleentheid van die eeufees. Johannesburg : Dagbreekpers. p. 13-27.)

VAN ROOY, H.F. 1998. Die PU vir CHO as Christelike universiteit. (In KOERS. Verkennings in oorgang. Gedagtes by die 125-jarige bestaansjaar van die PU vir $\mathrm{CHO}$ - 1994. Supplement 1. Orkney : EFJS. p. 87-116.)

VAN ROOY, J.A. 1995. Die bydrae en relevansie van die missiologiese besinning in die GKSA. In die Skriflig, 29(1\&2):221-240, Maart/Junie.

VAN WYK, J.H., red. 2001. Kerk- en Christenwees vandag. Potchefstroom : PTP.

VORSTER, J.M. 1996. Is die kerk funksioneel? Gedagtes oor gereformeerde kerkvernuwing in 'n post-moderne konteks. Potchefstroom : PTP.

VORSTER, N. 2002. Kerk en menseregte binne 'n regstaat. Die profetiese roeping van die kerk ten opsigte van die vestiging van 'n etos van menseregte in SuidAfrika. Potchefstroom : PU vir CHO. (Th.D.-proefskrif.)

\section{Kernbegrippe:}

eenheid

ekumenisiteit

Gereformeerde Kerke in Suid- Afrika, 1859-2002

roeping

\section{Key concepts:}

calling ecumenicity

Gereformeerde Kerke in Suid- Afrika, 1859-2002 unity 